Biosemiotics 17

Gianfranco Marrone Dario Mangano Editors

Semiotics

of Animals

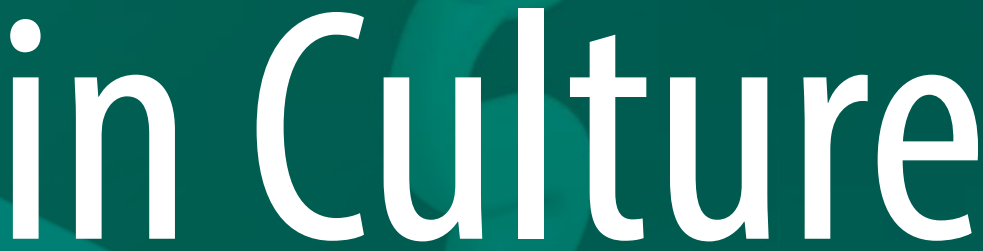

Zoosemiotics 2.0

Springer 


\section{Biosemiotics}

\section{Volume 17}

\section{Series editors}

Jesper Hoffmeyer, Professor emeritus in biochemistry, University of Copenhagen Kalevi Kull, Professor in biosemiotics, University of Tartu

Alexei Sharov, National Institute of Aging, Baltimore 


\begin{abstract}
Aims and Scope of the Series
Combining research approaches from biology, semiotics, philosophy and linguistics, the field of biosemiotics studies semiotic processes as they occur in and among living systems. This has important implications and applications for issues ranging from natural selection to animal behaviour and human psychology, leaving biosemiotics at the cutting edge of the research on the fundamentals of life.

The Springer book series Biosemiotics draws together contributions from leading scholars in international biosemiotics, producing an unparalleled series that will appeal to all those interested in the origins and evolution of life, including molecular and evolutionary biologists, ecologists, anthropologists, psychologists, philosophers and historians of science, linguists, semioticians and researchers in artificial life, information theory and communication technology.
\end{abstract}

More information about this series at http://www.springer.com/series/7710 
Gianfranco Marrone - Dario Mangano Editors

\section{Semiotics of Animals in Culture}

Zoosemiotics 2.0

鱼 Springer 


\author{
Editors \\ Gianfranco Marrone \\ Culture \& Society \\ University of Palermo \\ Palermo, Italy
}

\author{
Dario Mangano \\ Culture \& Society \\ University of Palermo \\ Palermo, Italy
}

ISSN 1875-4651

Biosemiotics

ISBN 978-3-319-72991-6
ISSN 1875-466X (electronic)

ISBN 978-3-319-72992-3 (eBook)

https://doi.org/10.1007/978-3-319-72992-3

Library of Congress Control Number: 2018934409

(C) Springer International Publishing AG 2018

This work is subject to copyright. All rights are reserved by the Publisher, whether the whole or part of the material is concerned, specifically the rights of translation, reprinting, reuse of illustrations, recitation, broadcasting, reproduction on microfilms or in any other physical way, and transmission or information storage and retrieval, electronic adaptation, computer software, or by similar or dissimilar methodology now known or hereafter developed.

The use of general descriptive names, registered names, trademarks, service marks, etc. in this publication does not imply, even in the absence of a specific statement, that such names are exempt from the relevant protective laws and regulations and therefore free for general use.

The publisher, the authors and the editors are safe to assume that the advice and information in this book are believed to be true and accurate at the date of publication. Neither the publisher nor the authors or the editors give a warranty, express or implied, with respect to the material contained herein or for any errors or omissions that may have been made. The publisher remains neutral with regard to jurisdictional claims in published maps and institutional affiliations.

Printed on acid-free paper

This Springer imprint is published by the registered company Springer International Publishing AG part of Springer Nature.

The registered company address is: Gewerbestrasse 11, 6330 Cham, Switzerland 


\section{Contents}

Introduction: Towards Zoosemiotics $2.0 \ldots \ldots \ldots \ldots \ldots \ldots \ldots \ldots \ldots$

Gianfranco Marrone

\section{Part I Animal as Food, Food for Animals}

When to Eat Meat? Toward a Diet of Caring. . . . . . . . . . . . 21

Nicola Perullo

Anti-speciesist Rhetoric . . . . . . . . . . . . . . . . . . . . . . . 33

Matteo Meschiari

Aesthetics of Nutrition, Ethics of Animality: The Packaging

of Vegan and Vegetarian Products in the Italian Organised

Distribution Market

Ilaria Ventura Bordenca

Forms of Animality: The $\operatorname{Dog} \ldots \ldots \ldots \ldots \ldots \ldots \ldots$

Dario Mangano

Pet Food Communication: Notes on the Crisis of Naturalism . . . . . . . 73

Roberta Bartoletti and Giulia Cecchelin

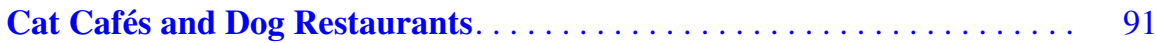

Alice Giannitrapani

The Birth of a Pet? The Rabbit . . . . . . . . . . . . . . . . . . . . . . 103

Francesco Mazzucchelli

Part II Animals in the Texts, Texts as Animals

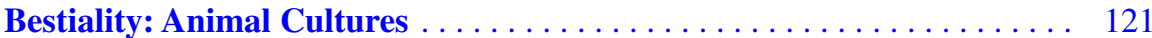

Gianfranco Marrone 
On the Logic of Animal Umwelten: The Animal Subjective Present and Zoosemiotics of Choice and Learning . . . . . . . . . . . . . 135 Kalevi Kull

Of Men, Dogs and Bears: Communication in the Wilderness . . . . . . . . 149 Tarcisio Lancioni

The Mixed Category Human-Animal in New Anthropology

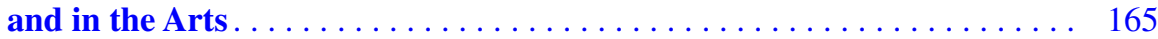
Tiziana Migliore

The "Morally Abandoned Child" and the "Inner Savage" . . . . . . . . . 181 Pierluigi Cervelli

Frank and Johnny with Evie: Ontological Shifts in a J.R. Ackerley Novel .

Francesco Mangiapane

The Human-Animal Relationship and the Musical Metaphor in The Great Animal Orchestra by Bernie Krause . . . . . . . . . . . . . . . 209 Emiliano Battistini 


\title{
The Mixed Category Human-Animal in New Anthropology and in the Arts
}

\author{
Tiziana Migliore
}

\begin{abstract}
Considering animality in terms of interdependency between humans and animals may help us understand how different species have evolved and continue to do so through time. The stakes are high. Darwinian evolutionary theories, while based on the continuity of the species and while suggesting the idea of mutual derivation, e.g. of humans from animals, are mostly concerned with the origins; they are not concerned with whether and how humans and animals have evolved together socially and culturally. Even a superficial look at contemporary society, with its habits, tastes and recurring trends in fashion, design and the arts, shows that the border between the two categories is nothing but a threshold: the Umwelt of the humans has evolved by borrowing from the Umwelt of the animals, creating hybrids and interspecies (Ramos, Animals. MIT Press, Cambridge, MA, 2016).

The article presents a few illustrations of the forms and force of this evolution, and highlights the obstacles that may prevent various disciplines from seeing it as it is, i.e. as a participatory process.
\end{abstract}

\section{Mimicking the Animal}

Semiotic research on mimicry and camouflage (Migliore 2008; Fabbri 2008, 2011; Casarin and Fornari 2010) tends to overlook a crucial fact: the chameleon's strategy shows not only that subjectivity is the result of a complex system of presentation and representation simulacra (of the self and of the other) (Fabbri 2008, p. 89) but also how a species may abandon its own physiological identity to adopt the physical and outer identity of another realm. The animal mimics the facies and the actorial, spatial and temporal characteristics of the environment in which it plans to hide; the soldier mimics the facies and the actorial, spatial and temporal characteristics - i.e. features, movements and behaviours - of animals that are good at hiding. The animal selects and adopts, that is, embodies, the most efficient defensive patterns of its own habitat; human beings select and embody the most efficient defensive and

\footnotetext{
T. Migliore $(\bowtie)$

University Ca' Foscari, Venezia, Italy

e-mail: tiziana.migliore@unive.it
} 
aggressive patterns of the animal. The oppositions human/environment and human/ animal are not binary but participatory.

But do humans simulate these features in the sense that they are lying? Not at all. They shed their skin and adapt so well to their environment that some of the characters, initially learned out of contingency, eventually become stable, "natural" and necessary. The semiosphere remains the same. The evolution of the species, which unfortunately does not coincide with their progress, is determined by the dissemination and consolidation of these mimicry strategies. Historically, studies on animal mimicry, such as that of Henry Walter Bates, have had a crucial impact on the hypotheses of Wallace and Darwin. ${ }^{1}$ René Thom provides extensive explanations of how such morphological mutations unfolded in time, going so far as to suggest that the shape of the predator's claw or beak may have adapted to the gradual increase or decrease in the size of the prey. Skin and shell are tactical interruptions of the prey's organic extension and counter the obstructive action of the predator's beak, fangs or claws (Thom 1988, p. 139). The highly sophisticated survival strategies of animals (Caillois 1960; Belpoliti 2015), often overlooked, could help us understand several human behavioural patterns, whether at war, during espionage operations or, more covertly, in everyday life.

Shall we then say, by extension, that homo homini lupus? If the claim may sound too extreme, it is a fact that the survivors are those who know how to run like leopards or slither like snakes, not those who move backwards like shrimps - "a passo di gambero", as suggested in the title of Umberto Eco's eponymous book (Eco 2006). The model of the human body, both at war and in everyday life, is based on the corporeality of animals.

These facts find no correspondence in the reflections on corporeality developed by speculative disciplines, raising the urgent issue of bridging this gap between experience and knowledge.

\section{The "Corpus Archetypus"}

At least since Polykleitos' Canon, Western culture has been dominated by a univocal notion of the body - anthropomorphic, self-standing and serving as the "Nullpunkt of all the dimensions of the world" (Merleau-Ponty 1964, p. 249). This point has been demonstrated for more than half a century by art historians focussing on perspective with a central vanishing point. In philosophy, this particular way of thinking about the body underlies the principle of subjectivity. Admittedly, twentieth-century thinkers did deconstruct the notion of the body as an enclosed and impervious referentiality, prior to sense, and insisted on aesthesia, including its noncodified and non-codifiable expressions, as the medium whereby the flesh and skin of corporeality, viewing and visible, partake in the world (Fabbri 1991; Fontanille

\footnotetext{
${ }^{1}$ See H. W. Bates, Letter to C. R. Darwin, 2 May 1863, in Darwin Correspondence Project, "Letter no. 4138", accessed on 24 March 2017, http://www.darwinproject.ac.uk/DCP-LETT-4138
} 
2004; Marrone 2005). In phenomenology, however, the scenario remains that of a subject with a purpose and grasp on objects, with protension and retention - the subject of Husserl's intentional act.

Thus, the theory of embodiment or of the "embodied mind", which locates cognition in the body and its sensorimotor processes (Varela et al. 1991; Lakoff and Johnson 1999), and its derived theory of the "extended mind", which suggests that the environment and environmental interaction play a constitutive role in the formation of mental processes (Clark and Chalmers 1998; Clark 2008; Wilson 2004), seriously challenged what Isabelle Stengers calls the greatest "partition" in Western thought and the greatest obstacle to the progress of knowledge: the Cartesian dualism between mind and body (Stengers 1997). Both "embodiment" and "extended mind" theories criticise the ideal of an archetypal intellect that produces everything and in which everything is produced, and argue that cognitive and mental processes are expressed in the body (embodiment) and in the environment (extended mind). The problem, however, is that these new theories have changed our notions of both mind and the environment without rethinking our notions of the body, as if the latter were a universal principle, something given a priori with a hypostatised form. The "body", which is at the core of the model of the embodied mind, seems in no need of any definition.

As a consequence, the main theorists of the "embodied mind" struggle to explain how the mind is actually embodied and why neurons are not sufficient:

Every living being categorizes. Even the amoeba categorizes the things it encounters into food or nonfood, what it moves toward or moves away from. The amoeba cannot choose whether to categorize; it just does. The same is true at every level of the animal world. Animals categorize food, predators, possible mates, members of their own species, and so on. How animals categorize depends upon their sensing apparatus and their ability to move themselves and to manipulate objects. Categorization is therefore a consequence of how we are embodied. We have evolved to categorize; if we hadn't, we would not have survived. Categorization is, for the most part, not a product of conscious reasoning. We categorize as we do because we have the brains and bodies we have and because we interact in the world the way we do. (Lakoff and Johnson 1999, pp. 17-18; italics mine)

In the next passage, Lakoff and Johnson return to the role of neurons and synaptic connections, since, in their view, "A small percentage of our categories have been formed by conscious acts of categorization, but most are formed automatically and unconsciously as a result of functioning in the world", so that "we do not, and cannot, have full conscious control over how we categorize" (ibidem, p. 18). And below:

Think of the properties of the human body that contribute to the peculiarities of our conceptual system. We have eyes and ears, arms and legs that work in certain very definite ways and not in others. We have a visual system, with topographic maps and orientation-sensitive cells that provides structure for our ability to conceptualize spatial relations. Our abilities to move in the ways we do and to track the motion of other things give motion a major role in our conceptual system. The fact that we have muscles and use them to apply force in certain ways leads to the structure of our system of causal concepts. What is important is not just that we have bodies and that thought is somehow embodied. What is important is that the peculiar nature of our bodies shapes our very possibilities for conceptualization and categorization. (ibidem, p. 18-19, italics mine) 
But how do we do this? Lakoff and Johnson's passage is relevant insofar as the capacity to categorise is attributed to both humans and animals and considered as an effect of their own embodiment. The category of the body, however, is constantly and openly treated as a given. According to the two authors, the "embodied mind" has no repercussion on the conception of the "body", which remains a priori: embodiment theories notwithstanding, "we have the brains and bodies we have" (ibidem, p. 18). Unlike evolutionary scientists, Lakoff and Johnson do consider how social and cultural coevolution may have unfolded since the origins. However, their hypotheses about categorisations do not even consider the possibility that the "body" may evolve in parallel.

Thus, we find that we have successfully overcome the myth of intellectus archetypus, but not the premise of the corpus archetypus, although the latter corresponds to the body on which the former is based. An approach so detached from the description of processes and practices inevitably overlooks the dynamic relationship between sema and soma, as well as the actualisation of the meanings through usage. Semiotics, the science that studies the life of signs inside social life (Saussure), must act as an intermediary between philosophical thought and concrete experiences. The semiologist must know how to become a "serial describer" (Paolo Fabbri).

\section{Interdependent Physicalities}

If we want to demonstrate how humans, through time, have observed and assimilated a number of behaviours borrowed from animal "societies", and hence the participatory nature of evolution, we need to debunk the myth of the single-body model. We should account, on the one hand, for the animal physical entity, and on the other, for the possibility of human-animal physical entities that are not separate but discontinuous - a realm in which evolution does not work by filiation but through the "cross-breeding" of heterogeneous terms. To begin with, one should note that humans tend to judge and ratify themselves on the basis of animal features. The examples are countless: fables with animal protagonists, expressions such as the above-mentioned "run like a leopard" or "slither like a snake", proverbs (homo homini lupus, "curiosity killed the cat", "pigs get fat, hogs get slaughtered"), the bestiaries that are at the origins of fabulous geographies and symbolic and hieroglyphical conceptions of the world and, finally, the genre of the caricature, which draws on the "dogma of physiognomy" that is on the "pseudo-Aristotelian idea according to which the human character can be determined from the similarity of the human countenance to that of certain animals" (Gombrich and Kris 1938, p. 319). This is quite the opposite of saying that humans project their own feelings and desires on animals. To the contrary, it is the animal world that offers organisational hints to humans. Thus, in caricature, "the unlike parts are united to give a new meaning. They form an animal in which the portrait of man lives on" (ibid.), so that "nel tutto appariscono essere essi [le persone ritratte] e nelle parti sieno variati" ("the portrayed subjects appear the same in the whole, but different in the single parts" Baldinucci 1681, entry "caricare", p. 111). 


\subsection{The Human/Animal Participatory Category: Detour and Access}

What is the best approach to define the interdependency between humans and animals? Deleuze and Guattari's notion of "becoming-animal" (Deleuze and Guattari 1980) remains anchored in a human perspective, despite its pivotal contribution to twentieth-century Western philosophy and its challenge to the assumptions of unchanging humanity and unbridgeable gap between Homo sapiens and "worldpoor" animals (Heidegger 1929-1930, Eng. transl. 1995, p. 177). "Becominganimal" broke with essentialism, caught humans in the duration of concatenation and contagion and inaugurated "a vision of life under the sign of immanence" (Cimatti 2013, p. 130, my transl.). It enabled the recognition of hybridisations with retroactive effects on the human system, modifying, contaminating and altering its identity (Marchesini 2002, p. 115). And yet, despite the shift from a static "I" to the "process" of becoming-other - me-you or me-he/she - the subject of action and becoming is still the human being.

An alternative would be to investigate the relationship between humans and animals through the "detour-and-access" approach used by François Jullien (1995) in his study of China. Building upon Foucault's notion of heterotopian shift, Jullien suggests a delocalisation into the animal's environment and habits, that is, into its Umwelt. This process would be no more "animalising" that the one described by Jullien is "chinesifying": the Foucauldian heterotopian shift involves adopting the position and perspective of the animal to then return to a cogito that has been transformed and reconfigured by the whole process. On a metalinguistic level, if the change of becoming-animal is brought about by time (the temporal aspect) - as humans shed their own identity and appropriate that of the animal - the heterotopian shift is a spatial one: we adopt the animal's position only temporarily but by embodying its perspective. The arts and the anthropology of the ontological turn both put this shift into practice: they conceive the animal's physical nature from the animal's perspective. This enables them to verify the thesis of the embodied mind, as the physical nature of humans is not addressed directly but in negative, through the animal.

\section{Animality in New Anthropology}

Over the past 30 years, i.e. parallel to the development of embodiment theories, anthropology has gone through the so-called ontological turn. The pivotal studies, most of which were conducted in Latin America, called for the abandonment of ontological monism (based on the idea of a single being endowed with a single truth), for the abandonment of the idea that all entities share an identical nature and for the existence of different worldviews with different values and modes of knowledge. 


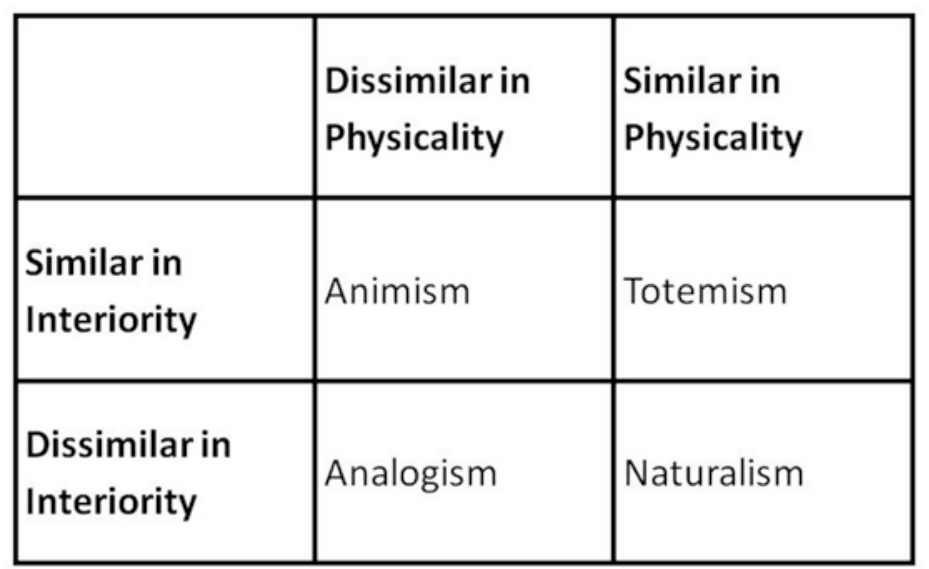

Fig. 1 Ontological scheme, the four modes (Descola 2005, p. 214)

In particular, Descola's (2005) classification into animistic, totemic, naturalist and analogical cosmologies, derived from Eduardo Viveiros de Castro (1998), frees us from our exclusive bond with Western naturalism, i.e. from the thesis of the original subject from whom everything is derived, and postulates the coexistence of multiple natures. According to Descola (op.cit.), animism implies inner resemblance and physical difference; totemism, inner and physical resemblance; naturalism, inner difference and physical resemblance; and analogism, inner and physical difference (Fig. 1).

\subsection{Animism}

What interests us in animistic mentality is the fact that it is founded on the principle of the inner continuity of the soul, hence the animistic belief in transmigration, and physical discontinuity, hence the belief that our bodies distinguish us. The soul remains formally identical throughout the species and is a reflexive form: it includes what it perceives from its own point of view; each body, to the contrary, is different and constitutes its own system of active, relational and transitive affections, expressed when becoming the object of the other's perspective. Thus, jaguars and humans are both predators from the point of view of a lamb; jaguars are predators and lambs are prey from the point of view of a human; and humans and lambs are both prey from the point of view of a jaguar (Viveiros de Castro 1998, p. 470).

This kind of "perspectivism", observed and theorised for the first time by anthropologist Tânia Stolze Lima, who studied the Juruna of Brazil, is different from relativism, which admits various points of view on a single reality (Lima 1996). There is no body in the sense of an a priori physiological essence with a series of undefined cognitions embodied in it, but a constellation of attitudes and habits that 
emerge in the form of points of view - that is to say, differences - and which determine the unique character of the body of a given species: what it eats and how it communicates. Knowledge is truly embodied because whatever is activated or "agented" by a point of view will be a person, in the sense of a concatenation of affects, affections and habitus - that is, as an instance of enunciation. Here Viveiros (1998) is amply quoting and using the linguistic and semiotic theories of Benveniste (1956, 1958).

\subsubsection{Animals as Deixis}

Animistic mentality raises two important reflections. The first is that the condition shared by humans and animals is not animality but humanity. The animistic model of the soul is human, while that of the body is animal. This worldview cannot imagine a polar opposition between Homo sapiens and animals, because it refuses any hierarchy based on the possession of language. It is no coincidence that Viveiros analysed animistic theories through the filter of Benveniste's system of the enunciation, which can also illustrate the mechanisms of extralinguistic communicative actions and reactions. The enunciation apparatus studies deictics and markers of objectivity and subjectivity in the framework of actual linguistic exchanges and speeches, i.e. parole, but its power of generalisation goes beyond verbal language. It lends itself quite well to describe cultures where the "subject" is not necessarily a speaking one. To the contrary, precisely because the model of the soul shared by humans and animals is the human soul, the Amerindian terms that are usually translated as "human being" do not actually refer to the natural category of the human species or to a member thereof, but to a person, an animated being in the pronominal sense - be it a human, a jaguar or a lamb - as a relational position (Viveiros de Castro 1998, p. 483), the marker of a presence.

Supposedly "human" characteristic are not the prerogative of humans. They are produced within the body. Individuals - as mentioned above - perceive the members of their own species as humanity, as culture. The species possesses a deictic us and, within the group, humanity is a reflexive property - the lamb is human to another lamb, and the jaguar is human to another jaguar. Contrariwise, identity, i.e. the difference among bodies that can only be perceived from an external point of view, is the product of a scopic function. The impersonal pronouns it and them indicate the non-person or the object, i.e. nature (ibidem, p. 483) Then there is the you, the second person (singular or plural) seen as the other subject of a nonhuman perspective, the supernatural, a dead persona or spirit. "Only shamans, multinatural beings by definition and office, are always capable of transiting the various perspectives, calling and being called 'you' by [non-human subjects] without losing their condition as human subjects" (ibidem).

In rituals, these pronominal functions are inverted. Human bodies, covered in feathers, colours, patterns, masks and other animal prostheses, are transformed into animals and reveal to their own eyes the "natural" peculiarity of their body. 
Interestingly enough, the moment of the maximum social objectification of bodies coincides with the moment of maximum animalisation (ibidem, p. 480).

\subsubsection{Vestments and Investments}

The second issue raised by the study of animism is that the nature of things changes in function of the habitus of the observer and is therefore the fruit of a complex combination of watching and being watched. Just as there is no a priori subject, there is also no fixed essence of things, but only the objective correlative of the point of view. In particular, the nature of what is observed is at the core of a "primary dialectic [...] between seeing and eating" (Mentore 1993, p. 29). "What to us is blood", writes Viveiros (1998, p. 478), "is maize beer to a jaguar; [...] what we see as a muddy waterhole, the tapirs see as a great ceremonial house". What varies is "what passes through the optic nerve (or digestive tube) of each species, so to speak" (Viveiros de Castro 2012, p. 34). There are no self-identical substances that are being categorised in different ways, but relational multiplicities such as bloodbeer or muddy waterhole-ceremonial house. In this dialectic:

1. Scopic functions are non-simultaneous. A human and a jaguar cannot be both "subjects", or rather "people", at the same time. A jaguar pouncing on a man sees the latter's blood as beer before the man has become aware of the peril. "Each species has to be capable of not losing sight, so to speak, of the fact that the others see themselves as people and, simultaneously, capable of forgetting this fact - that is, of - no longer seeing it" (ibidem, p. 34). This is particularly important when humans become predators, that is to say when they kill to eat. They must be the first to see so as not to be seen.

2. Although we must be capable of "not seeing" the animals we eat as they see themselves, sometimes it may be useful or even necessary to see how certain animals see and to see them as they are seen by other animals (ibidem). The self incorporates the point of view of the enemy. In order to avoid being eaten by the jaguar, we must adopt its point of view on itself, become the other by occupying the enemy's position towards us, but without letting us be overwhelmed by alterity.

3. Thus, the visible form of the body, which is a powerful sign of the differences between affections, is not a fixed entity but a variable and metamorphic appearance, an ever-changing and removable clothing. It can be deceptive: a human form may conceal a jaguar-affection. Appearances are misleading, not because they differ in their supposed essence, but precisely because they are appearances, i.e. something that appears. An appearance implies and is determined by a recipient, a subject in front of whom the act of appearing takes place. "It is not so much the body that is a clothing but rather that clothing is a body" (Viveiros de Castro 1998, p. 482). 


\subsection{Animistic Mentality in the West}

The merit of Viveiros was to show that the identification modes of animism are not limited to the practices of native populations, but that they are and have always been present in our world, too. Not for religious reasons or because Buddhism is currently in fashion. Animistic logic, whereby body and soul are effects of perspective and never a priori categories, may explain wartime camouflage, the mimicry and animal-like movements of soldiers, animal-rights movements as well as the recent evolution of eating habits and therefore of the food industry (Marrone 2011). Let us think of the controversy about eating meat. The main charge brought forward by vegans is that, by ingesting the flesh of animals, meat eaters also ingest the soul that these animals have in common with us. The argument of the defence is that, deep down, we are all cannibals, as humans always eat an alterity which they reduce to themselves through a variety of beliefs and rituals (Lévi-Strauss 2013). The former argument is "driven" by the firm animistic belief that animals embody a soul that we share, i.e. that their body, being "an assemblage of affects or ways of being that constitute a habitus" (Viveiros de Castro 1998, p. 478), incorporates a reflexive form that is equivalent to ours; the second argument, which is analogic, is ruled by a basic "exterior"/"interior" dichotomy between humans and the animals that humans reduce to their own life form. Only "a theory of the sign and communication" (Viveiros de Castro 2012, p. 35), i.e. semiotics, can give an explicit form to these controversies.

As proof that animism, just like any other worldview, has no geographic location but is a question of thought and beliefs, Viveiros borrows not only the notion of enunciation from Benveniste but also the idea of the soul as a concatenation of affects, affections and habitus from Deleuze: here "affect" is the acting power that increases or decreases according to the chance encounters in which the sentient body takes part; and "affection" is a composition of bodies, a relationship of mutual capture that triggers the alterations imposed by a body to another (Deleuze 1980). Deleuze, despite being a Western philosopher, is not a naturalist. His reference is another Western philosopher, Spinoza, who defined the affectus as "the modifications of the body, whereby the active power of the said body is increased or diminished, aided or constrained, and also the ideas of such modifications" (Spinoza 1677, Eng. trans. 2001, p. 4). Ethology itself, according to Deleuze, is based on the affects of which we are capable and which define the bodies:

\footnotetext{
The approach is no less valid for us, for human beings, than for animals, because no one knows ahead of time the affects one is capable of; it is a long affair of experimentation, requiring a lasting prudence, a Spinozan wisdom that implies the construction of a plane of immanence or consistency. Spinoza's ethics has nothing to do with orality; he conceives it as an ethology, that is, a composition of fast and slow speeds, of capacities for affecting and being affected on this plane of immanence. (Deleuze 1970, p. 125)
}

The interpretations of perspectivism in Lima, Viveiros and later Descola, also draw on Deleuze's "truth of relativity" as opposed to the "relativity of what is true": in a non-essentialist and phenomenical worldview, the subject is an event: a vector 
Fig. 2 Photogram from the American computeranimated comedy film Madagascar 1 (2005), DreamWorks Animation

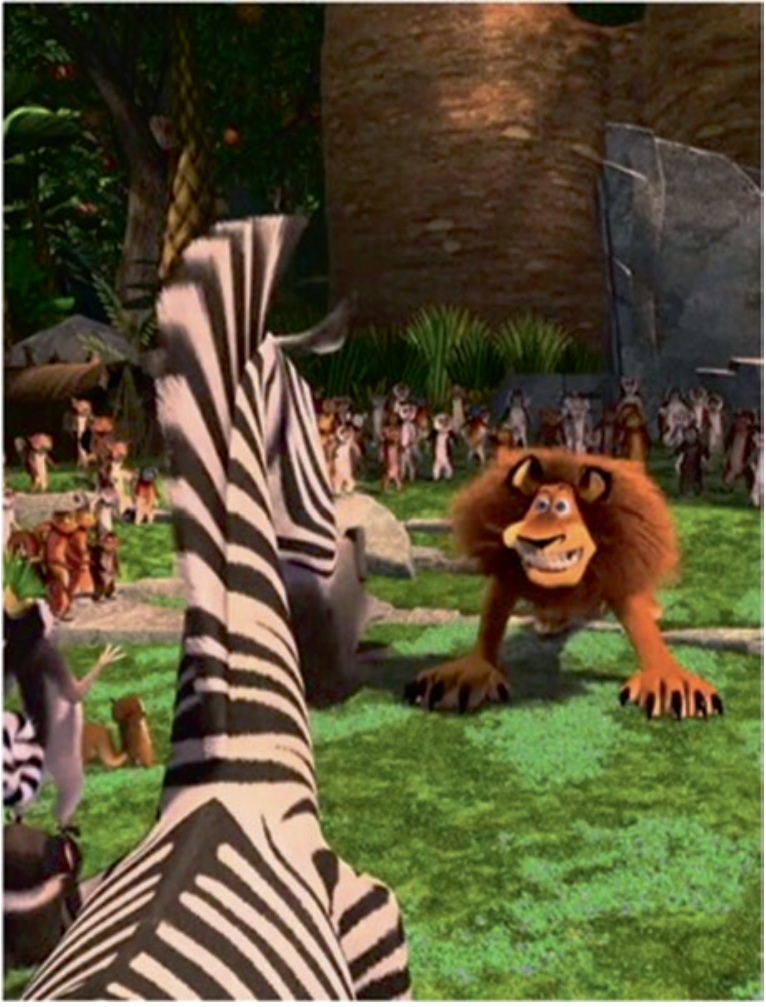

of curvature, the effect of what occupies the point of view and makes it what it is (Deleuze 1988), "pure powers whose act consists in habitus or arrangements (folds) in the soul" (ibid., Eng. trans. 2006: 24). ${ }^{2}$

Far from lending itself to criticism, the use of Western categories to explain animism merely demonstrates the existence of approaches alternative to naturalism in the West. Which is why we are not surprised by a scene such as the one featured in the animation film Madagascar 1 (2005), where Alex, a lion crazed by hunger, sees his zebra friend Marty as a steak (Figs. 2 and 3).

We may not be aware that what is at play is the change of affection of an animist, but the meaning of what is going on is perfectly clear. The four worldviews coexist - indeed, who is more totemic than a fetishist? - and do not belong to different worlds. In Madagascar 1, the commutation between zebra and steak illustrates the conception of things and subjects as relational terms: physical entities "vested" with the investments of the beholder and expressing and translating the latter's affections and affects. In this specific case, the contrast between the zebra's envelope-container and the meat-content expresses, semi-symbolically, its transformation from subjectentity to object-prey:

\footnotetext{
${ }^{2}$ On perspectivism in the anthropology of the ontological turn, see Migliore (2015).
} 


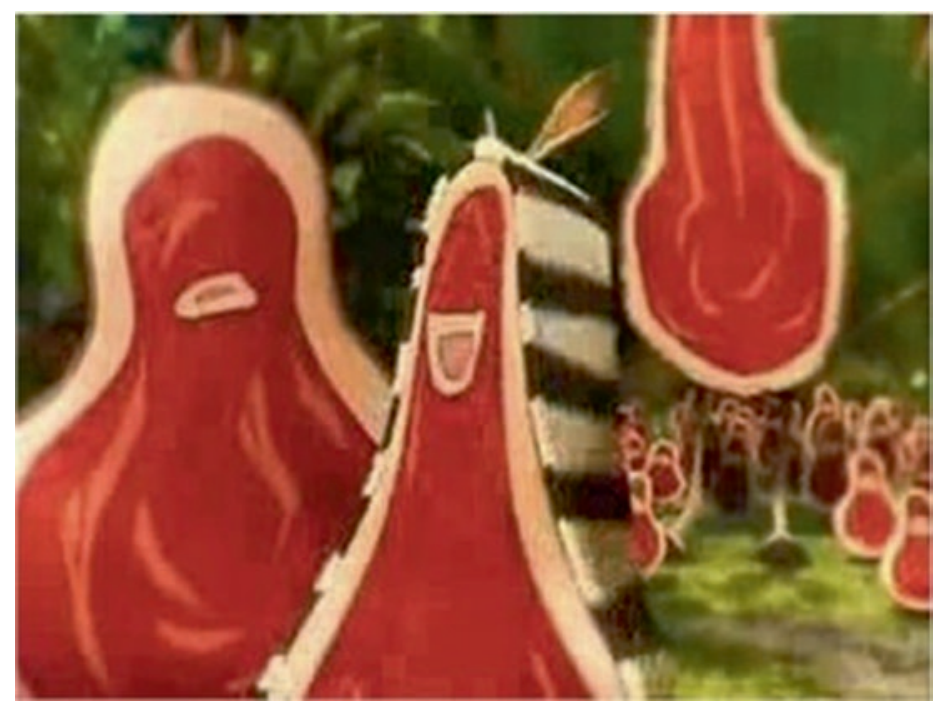

Fig. 3 Photogram from the American computer-animated comedy film Madagascar 1 (2005), DreamWorks Animation

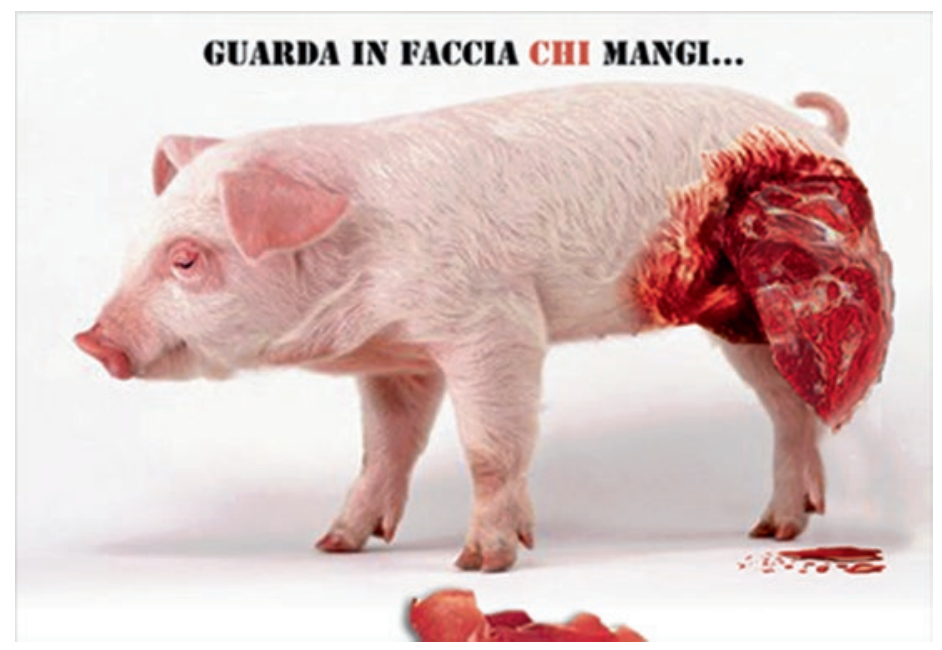

Fig. 4 Vegan sensibilisation campaign against the consumption of animal meat www.wired.it/ lifestyle/food

Black-and-white striped exterior: blood-red interior:: subject-entity: object-prey

Many pro-vegan campaigns resort to a similar strategy: they intimidate meat eaters by imposing their own animistic worldview (Fig. 4).

The anthropology of the ontological turn, which provides the tools to reflect upon these differences, brings up the proximal rather than distal relationship 
between animals and humans. The category /human/ cannot be defined without the category /animal/: in other words, /human/ and /animal/ mutually define each other. Moreover, the very notions of survival and social objectification, as well as civilisation, require the capacity to incorporate the animal's perspective. Thus, animals are not "nonhuman": "human" is a complex category" that includes the participatory subcategory/human/-/animal/. Viveiros de Castro (1998, p. 472) goes so far as to say that Animals are ex-humans (rather than humans, ex-animals). "The myths tell how animals lost the qualities inherited or retained by humans. Humans are those who continue as they have always been". "While our folk anthropology holds that humans have an original animal nature that must be coped with by culture - having been wholly animals, we remain animals 'at bottom' - Amerindian thought holds that, having been human, animals must still be human, albeit in an unapparent way. Thus, many animal species, as well as sundry other types of nonhuman beings, are supposed to have a spiritual component that qualifies them as "people"".

\section{Animality in the Arts}

Visual arts started with the creation of images that illustrated the continuity and contiguity between humans and animals. The first prehistoric pictorial subjects were animals painted with animal blood: these bison were not meant to represent a given event but rather to anticipate and bring luck to future hunting parties. The subjects, painted with the blood of preys, expressed the sacred nature of the animal that would save the group from starving (thanks to its meat) or freezing to death (thanks to its skin and furs).

\footnotetext{
An existential relationship was established between humans and animals. Animal life nourished human life [...]. The meal was the act through which spiritual symbiosis was achieved and completed by means of the integration of the animal spirit into a human body [...]. The representations of anthropomorphic beings masked as animals and of anthropo-zoomorphic beings in hunting art are a spectacular illustration of this search for symbiosis [...]. The death of one gives life to the other. The dead animal was a source of food and life. Through the physical assimilation of the flesh of the animal, humans also acquired its strength, vitality and all its capacities, both real and imaginary. (Anati 2002, p. 87, my translation)
}

Animal parts, secretions and other remains soon became ingredients in the preparation of colours (Elkins 1999), contributing to the painting's pictorial texture. Even the glues used in Renaissance painting were made from horse hooves, deer antlers or rabbit skins. Some glues used in modern painting are still made with animal skins. On the figurative front, the preservation of animal traits in the artwork was conveyed through two main channels: on the one hand, the animal vital force found its iconographic expression in the miniatures and on the capitals and gargoyles of cathedrals, which made reference to Medieval bestiaries; on the other, this energy symbolically functions as a metaphor for the survival of the artwork itself a metaphor ironically overturned in the interest in taxidermy and formaldehyde manifested by contemporary artists such as Annette Messager, Damien Hirst, or 


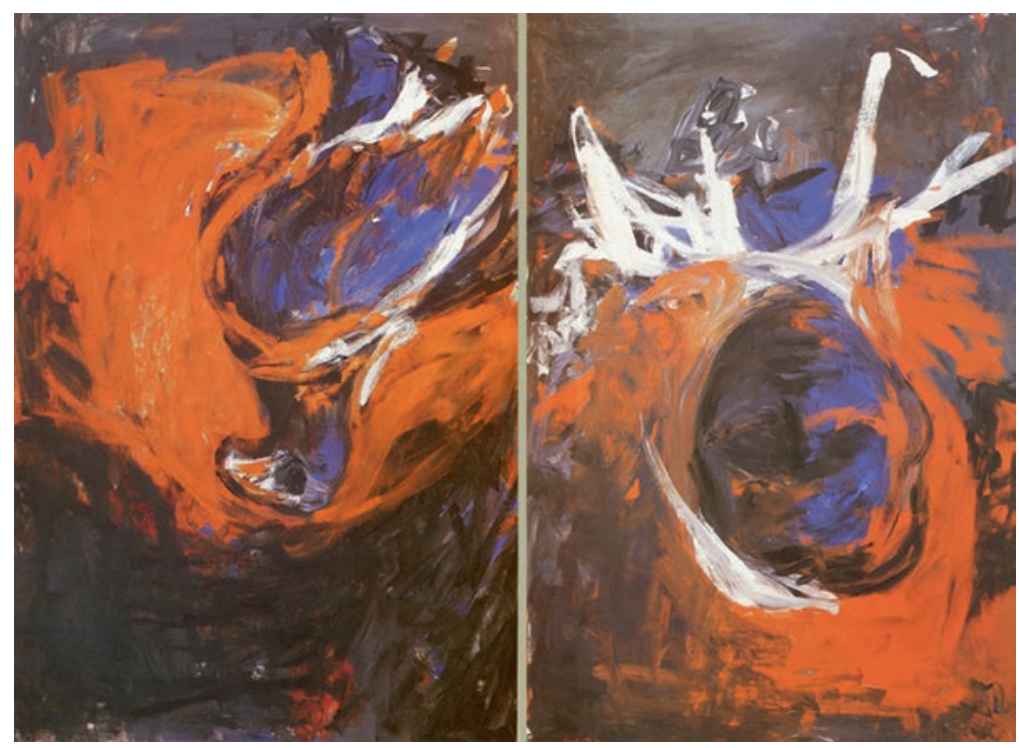

Fig. 5 Georg Baselitz, Portrait und Adler, 1978, $250 \times 340 \mathrm{~cm}$ (Private Collection)

Maurizio Cattelan. We should also mention the huge iconological contribution to zoosemiotic imagery and to the linguistic and metalinguistic meanings of animals, from lions to parrots and monkeys. Nowadays, numerous artists disguise themselves as animals (Ana Mendieta, Joan Jonas, Jan Fabre) or represent what they observe sub specie animalis (Alberto Savinio, Jean Dubuffet, Joseph Beuys).

Several impressive experiments have been carried out in order to develop an animal phenomenology (Broglio 2011), i.e. to work on the notion of interspecies through a heterotopian shift into the animal world (see Ramos ed., 2016). A case in point is Georg Baselitz's Portrait und Adler (1978), a $250 \times 340 \mathrm{~cm}$ diptych painted with oil and tempera on plywood (Fig. 5).

The diptych features two upside-down figures, painted in the same blue tones, with the same red shadows, black-and-white outlines and grey background: the full-body figure of an eagle, its beak turned to the side, on the left panel; and the head and shoulders of a man, seen from the front, on the right one.

Although the two backgrounds are painted in the same colour, the tones on the left are bright and saturated while those on the right are more blurred, suggesting that the two portraits may have been painted in the same place but at different times, dynamically and on the spot. The image freeze captures the two figures in what appears to be a reverse chronological order with respect to the title: following the Western left-to-right reading direction, the man (Portrait) should be on the left and the eagle (Adler) on the right. This is not the case, and only an aerial perspective from the bottom could justify the inversion and upside-down position. It is as if the perspective were that of a bird, perhaps another eagle, seeing an animal of its own species (a similar zoon) to its left (Adler) and an animal from a different species, a 
(zoon politikon) to its right (Portrait). What remains is the verbo-visual contradiction: Adler, in German, is both the common noun of the eagle and a proper noun; moreover, due to its character, the eagle has been the symbol of Germany ever since the times of Scandinavian myths - undergoing a series of semantisations and polarisations throughout the centuries.

Which figure, then, designates the Portrait and which one the Adler in Baselitz's painting? The answer lies in the animal staging of a mutual capture.

\section{References}

Anati, E. (2002). La struttura elementare dell'arte. Capo di Ponte: Edizioni del Centro.

Baldinucci, F. (1681). Vocabolario Toscano dell'Arte del Disegno. New Edition: Baldinucci, F. (1809). Società Tipografica de'Classici Italiani, Milano

Belpoliti, M. (2015). La strategia della farfalla. Parma: Guanda.

Benveniste, E. (1956). La nature des pronoms. In: M. Halle \& R. Jakobson (Eds.), For Roman Jakobson (pp. 34-37). The Hague: Mouton \& Co. Italian Edition: Benveniste, E. (2009). La natura dei pronomi. In P. Fabbri (Ed.), Essere di parola. Semantica, soggettività, cultura (pp. 138-143). Milano: Bruno Mondadori.

Benveniste, E. (1958). De la subjectivité dans le langage. Journal de Psychologie, 55, 257-265. Italian Edition: Benveniste, E. (2009). Della soggettività nel linguaggio. In P. Fabbri (Ed.), Essere di parola. Semantica, soggettività, cultura (pp. 111-118). Milano: Bruno Mondadori.

Broglio, R. (2011). Surface encounters: Thinking with animals and art. Minneapolis and London: University of Minnesota Press.

Caillois, R. (1960). Méduse et Cie. Paris: Gallimard. English Edition: Caillois, R. (1964). The mask of Medusa: the relationship and contrast between insect and man. New York: Clarkson N. Potter.

Casarin, C., \& Fornari, D. (2010). Estetiche del camouflage. Et al, Milano

Cimatti, F. (2013). Filosofia dell'animalità. Roma-Bari: Laterza.

Clark, A. (2008). Supersizing the mind: Embodiment, action, and cognitive extension. Oxford: Oxford University Press.

Clark, A., \& Chalmers, D. (1998). The extended mind. Analysis, 58, 7-19.

Deleuze, G. (1970). Spinoza: Philosophie pratique. Paris: PUF. English Edition: Deleuze, G. (1988). Practical philosophy. San Francisco: City Light Books.

Deleuze, G. (1980). De quoi une corps est-il capable? Cours sur Spinoza. Available http://www2. univ-paris8.fr/deleuze/rubrique.php3?id_rubrique=6. Accessed 6 Jul 2017. Italian Edition: Deleuze, G. (2013). Cosa può un corpo? Lezioni su Spinoza. Ombre Corte, Verona

Deleuze, G., \& Guattari, F. (1980). Mille plateaux: Capitalisme et schizophrénie. Paris: Seuil. English Edition: Deleuze, G., \& Guattari, F. (2003). A thousand plateaus: Capitalism and schizophrenia. Minneapolis: University of Minnesota Press.

Descola, Ph. (2005). Par-delà nature et culture. Paris: Gallimard. English Edition: Descola, Ph. (2013). Beyond nature and culture. Chicago: University of Chicago Press.

Eco, U. (2006). A passo di gambero. Guerre calde e populismo mediatico. Milano: Bompiani.

Elkins, J. (1999). What painting is. How to think about oil painting, using the language of alchemy. New York/London: Routledge. Italian Edition: Elkins, J. (2012). La pittura cos'è. Un linguaggio alchemico. Milano: Mimesis.

Fabbri, P. (1991). Il significante del mondo. New Edition In: Fabbri, P., \& Marrone, G. (Eds.) (2001). Semiotica in nuce II (pp. 328-335). Roma: Meltemi.

Fabbri, P. (2008). Estrategias del camuflaje - Entrevista de T Migliore. Revista de Occidente. José Ortega y Gasset, Madrid, Noviembre, 330, 89-110. 
Fabbri, P. (2011). Semiotica e camouflage. In S. Scalabroni (Ed.), Falso e falsi. Prospettive teoriche e proposte di analisi (pp. 11-25). Pisa: ETS.

Fontanille, J. (2004). Soma et séma. Figures du corps. Paris: Maisonneuve et Larose. Italian Edition: Fontanille, J. (2004). Figure del corpo. Per una semiotica dell'impronta. Roma: Meltemi.

Gombrich, E., \& Kris, E. (1938). The principle of caricature. British Journal of Medical Psychology, XVII, 319-342.

Heidegger, M. (1929-1930). Grundbegriffe der Metaphysik. English Edition: Heidegger, M. (1995). The fundamental concepts of metaphysics. World, Finitude, Solitude. Bloomington: Indiana University Press.

Jullien, F. (1995). Le détour et l'accès: Stratégies du sens en Chine, en Grèce. Paris: Grasset. English Edition: Jullien, F. (2000). Detour and access, strategies of meaning in China and Greece. New York: Zone Books.

Lakoff, G., \& Johnson, M. (1999). Philosophy in the flesh: The embodied mind and its challenge to western thought. New York: Basic Books.

Lévi-Strauss, C. (2013). Nous sommes tous des cannibales. Paris: Seuil. English Edition: LéviStrauss, C. (2015). We are all cannibals: And other essays. New York: Columbia University Press.

Lima, T. S. (1996). O dois e seu múltiplo: reflexões sobre o perspectivismo em uma cosmologia tupi. Mana, 2(2), 21-47. English Edition: Lima, T. S. (1999). The two and its many: Reflections on perspectivism in a Tupi cosmology. Ethnos, 64(1), 107-131.

Marchesini, R. (2002). Post-human. Verso nuovi modelli di esistenza. Torino: Bollati Boringhieri.

Marrone, G. (2005). La Cura Ludovico. Sofferenze e beatitudini di un corpo sociale. Torino: Einaudi.

Marrone, G. (2011). Addio alla natura. Torino: Einaudi.

Mentore, G. (1993). Tempering the social self: Body adornment, vital substance, and knowledge among the Waiwai. Journal of Archaeology and Anthropology, 9, 22-34.

Merleau-Ponty, M. (1964). Le Visible et l'Invisible suivi de Notes de travail. Paris: Gallimard. English Edition: Merleau-Ponty, M (1968). The visible and the invisible. Evanston: Northwestern University Press.

Migliore, T. (2008). L'efficacia del segreto. Strategie del mimetismo tra natura, guerra e arti. In T. Migliore (Ed.), Argomentare il visibile. Esercizi di retorica dell'immagine (pp. 223-231). Bologna: Esculapio.

Migliore, T. (2015). Sul prospettivismo. In G. Ferraro, A. Giannitrapani, G. Marrone, \& S. Traini (Eds.), Dire la natura. Ambiente e significazione (pp. 205-221). Roma: Aracne.

Ramos, F. (Ed.). (2016). Animals. Cambridge, MA: MIT Press.

Spinoza, B. (1677) Ethica ordine geometrico demonstrata. In: Opera posthuma. Amsterdam: Jan Rieuwertsz. English Edition: Spinoza, B. (1951). Ethics, demonstrated in geometrical order. In: R. H. M. Elwes (Ed.), The chief works of Benedict De Spinoza. New York: Dover.

Stengers, I. (1997). Cosmopolitiques, I, II. Paris: La Découverte. English Edition: Stengers, I. (2010). Cosmopolitics I, II. Minneapolis: University of Minnesota Press.

Thom, R. (1988). Esquisse d'une sémiophysique. Paris: InterEditions.

Varela, F., Thompson, E., \& Rosch, E. (1991). The embodied mind. Cognitive science and human experience. Cambridge, MA: MIT Press.

Viveiros de Castro, E. (1998). Cosmological deixis and Amerindian perspectivism. The Journal of the Royal Anthropological Institute, 4(3), 469-488.

Viveiros de Castro, E. (2012). Immanence and fear: Stranger-events and subjects in Amazonia. HAU: Journal of Ethnographic Theory, 2(1), 27-43.

Wilson, R. (2004). Boundaries of the mind: The individual in the fragile sciences. Cambridge: Cambridge University Press. 